\title{
Needs and skills for a national manpower force
}

\author{
D.J.J. van Rensburg \\ Rector: Technikon Pretoria \\ PRETORIA
}

\author{
G.J. Brink \\ Director: Personnel Administration \\ Technikon Pretoria \\ PRETORIA
}

\begin{abstract}
Needs and skills for a national manpower force

South Africa has been isolated from external business competition for many years. The political changes under way in the Republic are bringing with them the reality of international competition from world class players. In order to compete and survive, more attention will have to be devoted to the composition and quality of the South African work force. Education needs to be made more relevant to employment in terms of the skills required by the modern economic society. The workers of tomorrow will require a different and more sophisticated knowledge and skills portfolio than the workers of today and yesterday. An analysis of the needs and skills for a national manpower force is therefore appropriate.
\end{abstract}

\section{Introduction}

The political changes now under way in South Africa will have far-reaching implications for business in general and for the work force in particular. The removal of sanctions will open world markets to South African goods and services. At the same time, foreign firms will want a slice of this market. In other words, the information and technological revolution is changing the world of work on a macro scale. Capitalism is rampant, communism has collapsed, old regimes are falling and a new economic order is being forged. All over the world countries are reviewing their trade policies, restructuring their industries, and competition among nations and amongst companies is drastically increasing. South Africa's businesses and labour force have been isolated from external competition for many years and must now face up to the realities of international competition from world-class players (Kaljee, 1989:487).

Many local businesses have had a relatively easy time as cosy private arrangements and government protection have made it possible for them to set their own standards. In order to produce high-quality goods on a competitive basis, and to render outstanding services, more devotion is needed to the composition and 
quality of our work force. Education will have to be made more relevant to employment in order to improve the quality of the work force of South Africa (Coetzee, 1992:295).

\section{The present skills market in South Africa}

In the modern economic society it is generally accepted that the phrase labour market should be changed to skills market and that the workers of tomorrow will require a different and more sophisticated knowledge and skills portfolio than the workers of today and yesterday

The mix of skills that the skills market of tomorrow will require is virtually impossible to predict as it is affected by complex factors such as rapidly changing technologies, business strategies, politics, economic policy and the quality of the educational system. It will also be affected by legislation, work ethics, changing standards of living and the needs of the workers themselves (Fowler \& Karstens, 1991:1).

The skills market is a dynamic market and the availability of skills can be directly linked to changes in outputs of universities, technikons, technical colleges, schools, training centres, migration, renumeration packages for skills, image of the respective professions, and continuous training efforts of employers (Du Preez, 1988:1). The ideal mix of skills for South Africa will require a composition that optimally stimulates and develops the resources and potential of the country, and this mix will be influenced and driven by the needs of the employers (Guthrie-Morse, 1988:30)

In Table $l$ the general composition of South Africa's work force is shown in terms of high-, medium- and low-level manpower and the estimated needs by the year 2000 are also indicated. Although this estimate was made when sanctions were still being applied, the anticipated upswing in the economy will create an even higher demand for the welltrained in the nineties. Table $I$ indicates the anticipated shortage of high-level manpower that increased over the last two decades and the oversupply of medium-level manpower over the same period. High-level manpower is required for the technological development of a country. 
D.J.J. van Rensburg \& G.J. Brink

\section{Table 1}

The state of the labour market in 1980 and a forecast for the year 2000

\begin{tabular}{|c|c|c|c|}
\hline $\begin{array}{l}\text { Level of skill } \\
\text { (Manpower) }\end{array}$ & Demand & Supply & $\begin{array}{l}\text { Shortage (-) } \\
\text { Oversupply (+) }\end{array}$ \\
\hline & \multicolumn{2}{|c|}{$-1980-$} & \\
\hline High-level & 8660001 & 603000 & $-\quad 263000$ \\
\hline Medium-level & 1674000 & 1964000 & $+\quad 290000$ \\
\hline Low-level & 4995000 & 8227000 & +3232000 \\
\hline \multirow[t]{2}{*}{ Total } & 7535000 & 10794000 & +3935001 \\
\hline & \multicolumn{2}{|c|}{ - The year 2000- } & \\
\hline High-level & 1484000 & 1266000 & $-\quad 228000$ \\
\hline Medium-level & 2710000 & 6126000 & +3416000 \\
\hline Low-level & 5789000 & 10537000 & +4748000 \\
\hline Total & 9938000 & 17919000 & +7936000 \\
\hline
\end{tabular}

(The Institute for Futures Research, University of Stellenbosch, 1984)

\section{The imperative of continuous education}

A problem complicating the South African labour situation is that of a generation of disadvantaged youths who are functionally illiterate and do not possess the basic skills needed to become productive, self-supporting members of society. There is a risk of creating a permanent underclass, a group of people who are not just unemployed but also unemployable. For a balanced, dynamic work force the focus should be on basic education. Primary and secondary schooling must improve, giving the youth of South Africa the education they need for a productive and rewarding role within the work force.

The ideal of continuing education must become a reality. Every industry and every union should be involved in programmes to train, retrain and upgrade the skills of workers. It is imperative that the disadvantaged youth be offered the opportunity, through continuous education and training within industry (and the formal system of education), not only to improve their working skills but also to qualify for promotion to more senior positions. Wider recognition by educational institutions of qualifications obtained in industry and a freer flow of students between training boards and the formal educational system could do much to provide motivation to study and to improve the skills mix in the work force. Such a free flow of students between continuous training centres and institutions outside the formal educational system on the one hand and the formal education system on the other 
Needs and skills for a national manpower force

hand would indeed be the equilibrating factor between an unskilled, low-level work force and a highly skilled, balanced work force.

\section{Specific manpower needs}

\subsection{Engineering}

In 1990 the South African Council for Professional Engineers conducted an investigation into high-level manpower requirements in engineering in South Africa (Dutkiewicz, 1990)

The investigation showed that South Africa was producing approximately thirty per cent less engineering graduates than the minimum required for adequate longterm economic growth. Using the estimates of the shortage of engineers and the 'ideal' ratio of 1:3 for engineers and technicians, the shortage of qualified technicians was even more alarming. Table 2 shows the actual number of engineers and technicians who qualified in 1988 in relation to the desired numbers.

Table 2

Number of engineers and technicians required to graduate per year

\begin{tabular}{|l|c|c|}
\hline & Engineers & Technicians \\
\hline Number in 1988 & 1135 & 1835 \\
Desired number (1988) & 1476 & 4426 \\
Desired number (1995) & 1870 & 5610 \\
Desired number (2000) & 2270 & 6810 \\
\hline
\end{tabular}

(Dutkiewicz, 1990) (The totals for 1995 and 2000 were estimated using a GDP growth rate of $4 \%$ per annum.)

\subsection{Management training}

Acute shortages in technical manpower can be expected in the work force in future. A shortage of more than 200000 technically trained people is expected by the year 2000. In 198923000 artisans were trained, while between 100000 and 150000 should have been in training ( Nel \& Nel, 1990:30).

In surveys conducted in 1988 it was found that the manager to worker ratio in South Africa was 1:60. If the current trends continue, this ratio will deteriorate to 1:72 by 1995 and $1: 110$ by the year 2000 (Van Rooyen, 1991). The economic mix of South Africa should include one manager for every 25 workers. Similar 
studies in the United States found a ratio of one to six while Japan's ratio is one to ten (Van Rooyen, 1991).

It is clear that South Africa is not training sufficient managers and hence is not empowering its work force to take over managerial tasks at lower levels within the organisation. Current estimates are that there will be more than 200000 managerial vacancies by the year 2000 (Van Rooyen, 1991).

\subsection{High-tech information and service}

Between now and the year 2000, almost all new jobs will be in high technology, information and services, as opposed to the goods production of the past. The American Bureau of Labour Statistics (BLS) data covering industry employment over a longer period - between 1960 and 1995 - show a fairly steady increase in service-producing industry employment, while growth in the goods production employment is virtually nonexistent (Jones, 1987/88:21)

The Hudson Institute (Table 3) forecasts that between 1984 and 2000 there will be net declines in manufacturing, mining and agricultural employment, with all new jobs in non-goods producing industries, for example, computing, marketing, health and engineering. During the same period there will be a projected decrease of 400000 skilled and unskilled production jobs (Jones, 1987/88:21).

A detailed analysis of the reading, writing and vocabulary skills needed for the jobs of the future shows a direct correlation between the level of skills required and the growth rate of new jobs. Table 3 shows, for example, that the jobs with the highest growth rate require post-secondary education and higher order thinking skills.

Against the background of the present state of the South African labour market it is evident that South Africa will need more engineers, more scientists and technologists, many more technicians, more experts in advanced information systems, more managers, more entrepreneurs and a solid base of functionally literate workers equipped with relevant work ethics and basic skills. 
Needs and skills for a national manpower force

TABLE 3

Estimates of the percentage change in selected occupations in the USA

\begin{tabular}{|c|c|c|}
\hline \multicolumn{3}{|c|}{$1984-2000$} \\
\hline \multicolumn{2}{|l|}{ Selected occupations } & $\begin{array}{l}\text { Percentage change in employ- } \\
\text { ment between } 1984-2000\end{array}$ \\
\hline \multicolumn{2}{|l|}{ Lawyers and judges } & $94.88 \%$ \\
\hline \multicolumn{2}{|c|}{ Natural, computer and mathematical scientists } & 87.19 \\
\hline \multicolumn{2}{|c|}{ Health diagnosing and treating occupations } & 49.47 \\
\hline \multicolumn{2}{|l|}{ Social scientists } & 44.75 \\
\hline \multicolumn{2}{|l|}{ Marketing and sales } & 39.25 \\
\hline \multicolumn{2}{|l|}{ Managerial and management related } & 38.49 \\
\hline \multicolumn{2}{|l|}{ Engineers, architects and surveyors } & 37.02 \\
\hline \multicolumn{2}{|l|}{ Service occupations } & 36.66 \\
\hline \multicolumn{3}{|c|}{ (Within the service occupation the $100 \%$ is divided } \\
\hline \multicolumn{3}{|l|}{ as follows: } \\
\hline Food and beverage & $46.7 \%$ & \\
\hline Protection & 15.6 & \\
\hline Cleaning and building & 15.0 & \\
\hline Health & 12.3 & \\
\hline Personal & 4.9 & \\
\hline Private household & -2.4 & \\
\hline All other & 6.5) & \\
\hline Administrative support & & 22.61 \\
\hline Construction trades & & 19.62 \\
\hline Plant and system & & 16.01 \\
\hline Agriculture, forestry, fishing & & -15.50 \\
\hline Extractive and related & & -14.82 \\
\hline Blue-collar worker supervisors & & 8.85 \\
\hline Helpers, labourers, material movers & & 7.28 \\
\hline Machine setters, set-up operators, o & s, and tenders & -5.38 \\
\hline
\end{tabular}

(The Hudson Institute. In Jones, 1987:23.) 


\section{Changing skills needs of the labour market}

Apart from basic job skills there is also a definite change in the work force as far as other or job-related skills are concerned. As the demand and pay for higher and better trained workers increase, so do the expectations and standards concerning job-related skills. This is a new dimension emerging in career and vocational education - and in future much more attention will have to be devoted to the development of these job related skills. Many employers consider these skills more important than any other academic or vocational qualifications related to the job. The results of an unpublished study done at Technikon Pretoria by Fowler and Karstens (1991:8) on the skills needs of the South African labour market are shown in Table 4.

\section{Table 4}

Ranking of job-related skills in order of importance

\begin{tabular}{|l|l|l|l|l|}
\hline \multirow{2}{*}{$\begin{array}{l}\text { Rank } \\
\text { order }\end{array}$} & \multicolumn{1}{|c|}{ Skill } & \multicolumn{3}{|c|}{ Importance \% } \\
\cline { 3 - 5 } & & Not & Average & Very \\
\hline 1 & Reliability & 0,0 & 6,8 & 93,2 \\
2 & Perseverance & 0,9 & 10,3 & 88,9 \\
3 & Self-motivation & 0,0 & 12,7 & 87,3 \\
4 & Problem-solving & 0,0 & 12,7 & 87,3 \\
5 & Willingness to learn & 0,0 & 15,3 & 84,8 \\
6 & Being well-organised & 0,8 & 16,1 & 83,1 \\
7 & Initiative & 0,9 & 17,1 & 82,1 \\
8 & Punctuality & 1,7 & 16,2 & 82,1 \\
9 & Ability to adjust & 0,0 & 18,6 & 81,4 \\
10 & Understanding spoken & 0,0 & 19,5 & 80,5 \\
& instructions & & & \\
\hline
\end{tabular}

(See Fowler and Karstens, 1991:8.)

From this analysis it can be deduced that South African employers place a high premium on reliability as an important quality in the work place. This very quality also received the highest rating in a similar study (see Table 5) conducted by the Polytechnic of Wales' Recruitment and Training Research Unit. Qualities that also received a high rating in this investigation are willingness to learn and punctuality (Winiarski-Jones, 1987:17).

It appears from the findings of both the Technikon study and the Wales' study that employers, generally, expect more from students' training than the mere 
Needs and skills for a national manpower force

acquiring of standard technical abilities. There seems to be a need for a more enduring type of education to facilitate changes in the students personality for the duration of his career. The need for education, together with the necessary academic and practical skills, appears to be especially for internalised values such as reliability, perseverance, self-motivation and willingness to learn. Employers indicate a higher preference for these qualities in workers than, for example, external factors such as qualifications, experience, academic results and dress sense.

\section{Table 5:}

What employers look for in school leavers (Wales study)

\begin{tabular}{|l|l|l|l|}
\hline Skill & \multicolumn{3}{|c|}{ Importance \% } \\
\hline & Not & Average & Very \\
\hline Reliability and trustworthiness & 2 & 7 & 91 \\
Punctuality & 0 & 9 & 91 \\
Willingness to learn & 3 & 9 & 88 \\
Ability to work as member of a team & 1 & 14 & 85 \\
Enthusiasm & 1 & 17 & 82 \\
Clean and tidy appearance & 2 & 20 & 78 \\
Ability to work with minimum supervision & 1 & 33 & 61 \\
Initiative & 7 & 34 & 59 \\
Ability to work with figures & 14 & 30 & 56 \\
Ability to write clearly and concisely & 10 & 38 & 52 \\
Well-organised & 6 & 42 & 52 \\
Ability to speak fluently/with confidence & 9 & 40 & 51 \\
Friendliness & 12 & 44 & 44 \\
Some qualifications related to job & 43 & 22 & 35 \\
good "o": level/CSE in academic subjects & 39 & 31 & 30 \\
Qualifications in vocational subjects & 41 & 36 & 23 \\
Good dress sense & 39 & 38 & 23 \\
Some general work experience & 55 & 22 & 23 \\
Creativity & 34 & 46 & 22 \\
Work experience related to job & 63 & 16 & 21 \\
\hline
\end{tabular}




\section{Concluding remarks}

In many countries the mismatch between jobs being created and the skills of those seeking them will continue to grow. This is the challenge for South Africa. South Africa has one of the best education and training infrastructures in Africa, with an increasing output of skilled and well-qualified people each year. In order, however, to compete internationally, education will have to become more relevant in terms of quality and skills taught

\section{References}

COETZEE, D. 1992. Training as an Instrument to Combat Poverty and Unemployement: A National and International Perspective. Development Southern Africa, 9(3):295-315, August.

DU PREEZ, A.L. 1988. The Technikon in South Africa. Forum (Technikon Natal), 1(2):1-21.

DUTKIEWICZ, R.K. 1990. Engineering Education in South Africa. Study conducted for the South African Council for Professional Engineers

FOWLER, M. \& KARSTENS, L. 1991. Technikon Education: Adapting to the Changing Needs of the Labour Market. Research Report, Technikon Pretoria.

GUTHRIE-MORSE, B. 1988. The New Age. Community Technical and Junior College Journal, 58 (3):30-32

JONES, R.T. 1987/88. Influence Beyond the College Gates. AACJC Journal: 20-23, Dec/Jan.

KALJEE, A.1989. Challenges Facing the South African Industry in the Next Decade. The South African Mechanical Engineer, 39:487-492, Nov/Dec.

NEL, C. \& NEL, J. 1990. Demographic Realities Make Fundamental Change Inevitable. Human Resource Management: 30-33, February.

THE INSTITUTE FOR FUTURES RESEARCH. 1984. Report to the National Manpower Commission Stellenbosch : University of Stellenbosch

VAN ROOYEN, J. 1991. Die kwalitatiewe evaluering van bestuursontwikkeling. Referaat gelewer tydens simposium van die Nasionale Opleidingsraad, 12-14 Okt.

WINIWARSKI-JONES, T. 1987. How Close is the Partnership between Industry and Education? Transition: 17-19, June. 
